\title{
Effect of crude oil pollution on the oil-degrading bacteroids community in the nodules of Arachis hypogaea
}

\author{
T. Al-Ostad, N. Al-Mansour \& E. Al-Saleh \\ Department of Biological Sciences, Faculty of Science, \\ Kuwait University, Kuwait
}

\begin{abstract}
The exposure of the environment in Kuwait to crude oil pollution has detrimental effects on the ecological systems. The selective pressure created by the addition of crude oil is expected to impact the bacterial community structures of affected ecosystems such as the nodule bacteroids by enhancing the growth of crude oildegrading and/or tolerant microbiota. In the present study, the effect of crude oil on the structure of the crude oil-degrading nodule bacteroids community of Arachis hypogaea is investigated. Sequence analysis of $16 \mathrm{~S}$ rDNA amplified from nodule-bacteroids isolated from Arachis hypogaea grown in crude oil untreated and treated soils demonstrated the tendency of Gram negative bacteroids ( $\beta$-proteobacteria and $\gamma$-proteobacteria) to prevail in treated soils. Crude oil mineralization studies showed that predominant bacteroids have higher rates of crude oil mineralization $(5.5 \mu \mathrm{g} / \mathrm{min})$ compared to Gram positive bacteroids $(2.1 \mu \mathrm{g} / \mathrm{min})$. Furthermore, the effect of crude oil addition on nodules size, number and distribution was recorded. Bigger nodules (diameter of $3.13 \pm 0.058 \mathrm{~mm}$ ) were detected in untreated soil compared to that of treated soil (diameter of $1.97 \pm 0.122 \mathrm{~mm}$ ). In addition, the distribution of nodules on different parts of roots of untreated and treated plants was significantly different $(\mathrm{P}<0.05)$. Higher numbers of nodules were detected in the upper parts of the roots of Arachis hypogaea grown in untreated and treated soils $(124 \pm 0.455$ and $79 \pm 1.10$ nodules/plant respectively) compared to that observed in the lower parts of the roots ( $76 \pm 1.13$ and $7 \pm 0.31$ nodules/plant respectively). However, highest number of nodules $(200 \pm 0.361$ nodules/plant) was recorded for plants grown in untreated soils followed by that of treated soils ( $86 \pm 1.4$ nodules/plant). These results are discussed in the context of using Arachis hypogaea to restore degraded soils and to bioremediate crude oil contamination in Kuwait.

Keywords: arachis hypogaea, nodule, crude oil, bacteroids, $16 S$ rDNA, proteobacteria.
\end{abstract}




\section{Introduction}

Environmental disaster left by the Iraqi aggression against Kuwait in 1991 is one of the worst environmental disasters that struck the world in the twentieth century, where the aggressor Iraqi destruction and burning of more than (670) oil wells. It also deposited such huge quantities of crude oil, which led to formation of the so-called oil lakes covering about more than $49 \mathrm{~km}^{2}$ of the Kuwait desert. Crude oils are mostly composed of alkanes, cycloalkanes, various aromatic hydrocarbons and trace amounts of metals such as iron, nickel, copper and vanadium [12]. Because of the low water solubility of these compounds, they deposit in soil for long time [11]. Thus, spillage of crude oil into the environment will result in hydrocarbon and heavy metals contamination [1]. Some microorganisms survive in contaminated soil because they are metabolically capable of utilizing its resources. Hydrocarbon contaminated soil is often potential carbon and energy sources for microorganisms [22].

Microbial number, diversity and activity can be affected by hydrocarbons contamination $[3,16]$. It has been established that Gram-negative genera predominated in hydrocarbons contaminated soils [3]. Many reports indicated that the most prevalent hydrocarbon degrading bacteria belong to the genera Pseudomonas, Achromobacter, Nocardia, Arthorobacter, Bacillus, Micrococcus and Acintobacter [8, 14, 15]. The effect of crude oil on germination and growth of some plants has been studied $[2,10,20]$. However certain plants are able to remediate pollutant from soil. Phytoremediation is the use of plants and their associated microorganisms to clean up soil, sediment, and water contaminated with organic compounds and metals [13]. Legumes associate with bacteria that exist in the rhizosphere and nodules. Some of the rhizospheric bacteria are oilutilizing bacteria and have high potential for the bioremediation of crude oil contaminated soils $[10,18,19]$. In addition, legumes are able to fix nitrogen by nodule bacteroids enriching degraded soils. In this study the effect of crude oil addition on the nodulation and crude oil-degrading nodule bacteroids community of the legume, Arachis hypogaea (peanut), was studied. Also, the potential of isolated nodule bacteroids to mineralize crude oil was investigated.

\section{Materials and methods}

\subsection{Plant growth}

Seeds of peanut plants (Arachis hypogaea) were purchased from market and garden soil was obtained from Green House at Kuwait University. Before sowing peanut seeds were sterilized with $70 \%$ ethanol followed by soaking in sterile water. Peanut seeds were germinated in plastic trays containing garden soil for 4days. When germination completed only healthy seedlings were transplanted to other plastic pots (2 seedlings per plastic pot) containing different treatment of soil. Soil was divided into two main groups untreated soil used as control and soil treated with crude-oil (final concentrations were: 1 , and $5 \mathrm{ml} / 100 \mathrm{~g}$ soil). Seedlings were grown under controlled growth 
conditions in a growth chamber $\left(25^{\circ} \mathrm{C}\right.$ and humidity 50$)$ and were watered on daily basis with sterile water $(200 \mathrm{ml}$ per plastic pot) throughout the course of experiments. At 90 days after sowing, plants were carefully harvested along with the roots and gently washed with the tap water followed by sterile distilled water to remove the soil particles from root [21]. Nodules size, number and spatial distribution of nodules are determined in upper and lower parts of roots under stress [7].

\subsection{Isolation and identification of crude oil degrading bacteria from nodules}

The total crude oil degrading bacteria in nodules were counted using standard plate dilution method. Nodules were detached from roots, washed thoroughly three times with $70 \%$ ethanol and sterile water. Each group of nodules were weighed, smashed with sterile metal bar to release bacteroids, suspended in sterile $40 \mathrm{ml}$ of $50 \mathrm{mM}$ phosphate buffer ( $\mathrm{pH}$ 7.2) and gently mixed for $1 \mathrm{~min}$. After that, serial dilutions were prepared and $0.1 \mathrm{ml}$ aliquots were spread on nutrient agar and Hunter's minimal agar plates. Nutrient agar media was incubated at $30^{\circ} \mathrm{C}$ for 24 hours and Hunter's minimal agar plates were incubated under crude oil vapour at $30^{\circ} \mathrm{C}$ for the required time (2-14 days). Grown colonies were counted and expressed as colony forming unit (cfu) $\mathrm{g}^{-1}$ nodule. Isolated bacteria were Gram stained and identified by sequencing $16 \mathrm{~S}$ rDNA gene. For this purpose, genomic DNA was purified from pure bacterial cultures using the Wizard Genomic DNA purification kit as recommended by the manufacturer (Promega). Then, the 16S rRNA gene was amplified using polymerase chain reaction (PCR). Amplification was performed using puReTaq Ready to Go PCR beads (Amersham Biosciences) according to manufacturer's recommendations, 200 pmol of mixture of the two primers used 27F (5'-CUACUACUACUAAAG GAGGTGWTCCARCC-3') and 1492R (5'-GAATTCTACGGYTACCTTGTTA CGACTT-3') was added. The reactions were amplified using (GeneAmp PCR system 9700, Applied Biosystem). The PCR program used was a touchdown protocol. It started with an initial denaturation step at $94^{\circ} \mathrm{C}$ for $5 \mathrm{~min}$, followed by a denaturation step at $94^{\circ} \mathrm{C} 45 \mathrm{~s}$, annealing step at $56^{\circ} \mathrm{C}$ for $45 \mathrm{~s}$, and an extension step at $72^{\circ} \mathrm{C}$ for $1 \mathrm{~min}$. Annealing temperature was decreased by $2^{\circ} \mathrm{C}$ each 6 cycles for a total of 30 cycles. A final extension step was carried at $72^{\circ} \mathrm{C}$ for 7 min. Products were analyzed by gel electrophoresis where $5 \mu 1$ of each samples was run on $0.5 \%(\mathrm{w} / \mathrm{v})$ agarose gel along with $1 \mathrm{~kb}$ DNA ladder.

The PCR products obtained were purified using a Nucleospin Extract II kit (Macherey-Nagel, USA). The purified products were amplified using big dye terminator cycle sequencing kit according to manufacturer's instructions. The mixtures were incubated in the thermocycler at $96^{\circ} \mathrm{C}$ for 1 minute followed by 25 cycles of denaturation at $96 \mathrm{C}^{\circ}$ for 1 minute, annealing at $50^{\circ} \mathrm{C}$ for $5 \mathrm{~s}$ and extension at $60^{\circ} \mathrm{C}$ for 4 minutes. The final products were further purified, using $3 \mu \mathrm{l}$ of $3 \mathrm{M}$ sodium acetate $\mathrm{pH} 4.6,62.5 \mu \mathrm{l}$ of nondenatured $95 \%$ ethanol and 14.5 $\mu l$ of deionized water. Samples were incubated in dark at room temperature for 
20 minutes before being centrifuged at $15,000 \mathrm{xg}$ in room temperature for 20 minutes. The pellet formed was washed with $250 \mu \mathrm{l}$ of $70 \%$ ethanol and recentrifuged at $15,000 \mathrm{xg}$ in room temperature for 5 minutes. The pellets were airdried for 10-15 minutes in the hood. Dry pellets were re-suspended in $20 \mu \mathrm{l}$ of Hi-Di-Formamide and loaded directly in the 3130xl genetic analyzer (Applied Biosystems). Sequence analysis and GeneBank database searches were performed by using the BLAST program [5].

\subsection{Crude oil mineralization by isolated nodule bacteroids}

The amounts of carbon dioxide evolved were measured using a Micro-oxymax respirometer (Columbus instruments, USA) [4]. The reaction vessels contain: 49 $\mathrm{ml}$ sterile Hunter's minimal medium, $1 \mathrm{ml}$ of overnight bacterial suspension (OD $=1$ at $\lambda 600 \mathrm{~nm})$ and crude oil $(200 \mu \mathrm{l}))$. The reaction bottles were incubated in a shaking water bath at $30^{\circ} \mathrm{C}$. The amount of carbon dioxide evolved was plotted against time and the rate of carbon dioxide evolution was calculated.

\subsection{Statistical analysis}

All experiments values were conducted in triplicates and the mean with standard error of the mean were calculated using Minitab version 15 and SPSS package version 15 .

\section{Results and discussion}

\subsection{Effect of crude oil on the nodulation of untreated and treated plants}

The effect of crude oil addition on the number, size and distribution of nodules of untreated and treated Arachis hypogaea was tested and the results are shown in Table 1 . Highest numbers of nodules $(200 \pm 0.36$ nodules/plant) were recorded for untreated plants followed by that for plants grown in soil amended with $1 \mathrm{ml}$ crude oil $(100 \pm 1.18$ nodules/plant) and $5 \mathrm{ml}$ crude oil $(86 \pm 1.40$ nodules/plant $)$. Whereas all untreated and treated plants formed nodules, the number, size and distribution of nodules varied significantly $(\mathrm{P}<0.05)$. Higher numbers of nodules were detected in the upper part of the roots compared to the lower part of all tested plants with the highest numbers recorded for plants grown in untreated soil (124 \pm 0.46 nodules/plant) followed by those of plants grown in treated soil with $1 \mathrm{ml}$ and $5 \mathrm{ml}$ crude oil (per100g soil) $(86 \pm 1.40$ and $79 \pm 1.10$ nodules/plant respectively). Moreover, plants grown in untreated soil produced bigger nodules (diameter of $3.13 \pm 0.058 \mathrm{~mm}$ ) than those produced by plants grown in treated soils with $1 \mathrm{ml}$ and $5 \mathrm{ml}$ crude oil (diameter of $1.97 \pm 0.12 \mathrm{~mm}$ and $1.47 \pm 0.12 \mathrm{~mm}$ respectively). The toxic effect of crude oil recorded in the present study is consistent with previous reports on the inhibitory effect of crude oil on the growth of different plants $[2,6,9,10,20]$. 
Table 1: $\quad$ Effect of crude oil on the number, size and distribution of nodules of Arachis hypogaea.

\begin{tabular}{ccccc}
\hline \multirow{2}{*}{$\begin{array}{c}\text { Treatment with } \\
\text { crude oil }\end{array}$} & \multicolumn{3}{c}{ Nodule } \\
\cline { 2 - 3 } & \multicolumn{3}{c}{ Number / plant root } & Diameter \\
\cline { 2 - 3 } & Upper part & Lower part & Total & $(\mathrm{mm})$ \\
\hline $\begin{array}{c}\text { Untreated } \\
\text { (control) }\end{array}$ & $124 \pm 0.46$ & $76 \pm 1.13$ & $200 \pm 0.36$ & $3.13 \pm 0.06$ \\
Treatment with 1 ml & $86 \pm 1.40$ & $14 \pm 0.36$ & $100 \pm 1.18$ & $1.97 \pm 0.12$ \\
& & & & \\
Treatment with 5 ml & $79 \pm 1.10$ & $7 \pm 0.31$ & $86 \pm 1.40$ & $1.47 \pm 0.12$ \\
\hline Values are means of 25 determinations with standard error of mean (SEM).
\end{tabular}

\subsection{Effect of crude oil on bacteroids community structure}

The crude oil-degrading bacteroids in nodules were isolated using Hunter's minimal agar with crude oil as the sole source of carbon and energy. Several genera were isolated including Alcaligenes, Bordetella, Pseudomonas, Stenotrophomonas, Bacillus, Microbacterium and Streptomyces. The majority of crude oil-degrading bacteroids $(80 \%)$ isolated from untreated plants belonged to the Firmicutes and Actinobacteria (Table 2). On the other hand, treatment with crude oil resulted in the dominance of Gram negative bacteroids belonging to $\beta$ proteobacteria and $\gamma$-proteobacteria. Crude oil mineralization studies (Table 2) showed that predominant bacteroids have higher rates of crude oil mineralization $(5.5-3.7 \mu \mathrm{g} / \mathrm{min})$ compared to Gram positive bacteroids $(2.1-0.5 \mu \mathrm{g} / \mathrm{min})$. The higher rates of crude oil mineralization by the Gram negative bacteroids could be

Table 2: $\quad$ Isolated crude oil-degrading bacteriods and their rate of crude oil mineralization.

\begin{tabular}{lccc}
\hline Microorganisms & $\begin{array}{c}\text { Taxonomic } \\
\text { division }\end{array}$ & $\begin{array}{c}\text { Site of } \\
\text { isolation }\end{array}$ & $\begin{array}{c}\text { Rate of crude oil } \\
\text { mineralization } \\
(\boldsymbol{\mu g} / \mathbf{m i n})\end{array}$ \\
\hline Bordetella $s p$ & $\beta$-proteobacteria & & 5.5 \\
Pseudomonas $s p$ & $\gamma$-proteobacteria & $\begin{array}{c}\text { Crude oil } \\
\text { treated plants }\end{array}$ & 4.7 \\
Stenotrophomonas & & & 3.9 \\
sp & $\gamma$-proteobacteria & & 3.7 \\
Alcaligenes $s p$ & $\beta$-proteobacteria & & 2.1 \\
Bacillus cereus $s p$ & Firmicutes & & 1.0 \\
Microbacterium $s p$ & $\begin{array}{c}\text { Actinobacteria } \\
\text { Streptomyce } s p\end{array}$ & $\begin{array}{c}\text { Crude oil } \\
\text { Actinobacteria }\end{array}$ & $\begin{array}{c}\text { untreated } \\
\text { plants }\end{array}$ \\
Bacillus $s p$ & Firmicutes & & 0.6 \\
\hline
\end{tabular}


the explanation for the prevalence of Gram negative bacteroids in crude oil treated plants. Furthermore, isolated bacteroids demonstrated the potential to fix nitrogen (data not shown). The ability of rhizospheric bacteria of legumenous crops to enhance crude oil degradation was reported previously [17] but this is the first report showing the potential of Arachis hypogaea bacteroids to utilize crude oil and the feasibility of using Arachis hypogaea for the phytoremediation of crude oil contaminated sites and restoration of degraded soils.

\section{References}

[1] Tissot, B.P., \& Welte, D.H., Petroleum formation and occurrence: A new approach to oil and gas exploration. Springer-Verlag: New York, pp. 538, 1978.

[2] Adam, G. \& Duncan, H., Influence of diesel fuel on seed germination. Environmental Pollution, 120, pp. 363-370, 2002.

[3] Akpor, O.B., Igbinosa, O.E., \& Igbinosa, O.O., Studies on the effect of petroleum hydrocarbon on the microbial and physico-chemicals characteristics of soil. African Journal of Biotechnology, 6(16), pp. 1939 1943, 2007.

[4] AL-Saleh, E.S. \& Obuekwe, C., Inhibition of hydrocarbon bioremediation by lead in a crude oil-contaminated soil. International Biodeterioration \& Biodegradation, 56, pp. 1-7, 2005.

[5] Altschul, S. F., Madden, T.L., Schaffer, A.A., Zhang, J., Zhang, Z., Miller, W.,\& Lipman, D.J, Gapped BLAST and PSI-BLAST: A new generation of protein database search programs. Nucleic Acids Research, 25, pp. 3389-3402, 1997.

[6] Amadi, A., Dickson, A.A., \& Maate, G.O., Remediation of oil polluted soils. I. Effect of organic and inorganic nutrient supplements on the performance of maize (Zea may L.). Water, Air Soil Pollution, 66, pp. 59$76,1993$.

[7] Aryal, U.K., Hossain, M.K. , Mridha, M.A.U. and Xu, H.L., Nodulation status and nitrogenous activities of some legume tree species of Bangladesh. Journal of Crop Production, 3(1), pp. 325-335, 2000.

[8] Atlas, R.M., \& Cerniglia, C.E., Bioremediation of petroleum pollutants. Bioscience, 45, pp. 332-338, 1995.

[9] Baek, K.-H., Kim, H.-S., Oh, H.-M., Yoon, B.-D., Kim, J. \& Lee, I.-S., Effect of crude oil, oil components and bioremediation on plant growth. Journal of Environmental Science and Health, A39(9), pp. 2465-2472, 2004.

[10] Baker, J.M., The effects of oils on plants. Environmental Pollution, 1, pp. 27-44, 1970.

[11] Churchill, S.A., Harper, J.P. \& Churchill, P.F., Isolation and characterization of a mycobacterium species capable of degrading threeand four-ring aromatic and aliphatic hydrocarbons. Applied and Environmental Microbiology, 65(2), pp. 549-552, 1999. 
[12] Colwell, R.R. \& Walker, J.D., Ecological aspects of microbial degradation of petroleum in the marine environment. Critical Reviews in Microbiology, 5, pp.423-445, 1977.

[13] Cunningham, S.D., Anderson, T.A., Schwab, A.P., \& Hsu, F.C., Phytoremediation of soils contaminated with organic pollutants. Advances in Agronomy, 56, pp. 55-114, 1996.

[14] Ezeji, E.U., Anyanwu, B.N., Onyeze, G.O.C., \& Ibekwe, V.I., Studies on the utilization of petroleum hydrocarbon by microorganisms isolated from oil-polluted soil. International Journal of Natural and Applied Sciences, 1(2), pp. 122-128, 2005.

[15] Khan, K., Naeem, M., Arshed, M.J., \& Asif, M., Extraction and characterization of oil degrading bacteria. Journal of Applied Sciences, 6(10), pp. 2302-2306, 2006.

[16] Obire, O., \& Nwanbet, O. Effects of refined petroleum hydrocarbon on soil physico-chemical and bacteriological characteristics. Journal of Applied Sciences and Environmental Management, 6(1), pp. 39-44, 2002.

[17] Radwan, S.S., Al-Awadhi, H. \& El-Nemr, I.M., Cropping as a phytoremediation practice for oily desert soil with reference to crop safety as food. International Journal of Phytoremediation, 2(4), pp. 383-396, 2000.

[18] Radwan, S.S., Al-Awadhi, H., Sorkhoh, N.A., \& El-Nemr, I.M., Rhizospheric hydrocarbone utilizing microorganisms as potential contributors to phytoremediation for the oily Kuwaiti desert. Microbiological Research, 153, pp. 247-251, 1998.

[19] Radwan, S.S., Sorkhoh, N.A., \& El-Nemr, I.M., Oil biodegradation around roots. Nature, 376, p. 302, 1995.

[20] Shahriari, M.-H., Savaghebi-Firoozabadi, G., Azizi, M., Kalantari, F. \& Minai-Tehrani, D., Study of growth and germination of Medicago sativa (Alfalfa) in light crude oil-contaminated soil. Research Journal of Agriculture and Biological Sciences, 3(1), pp. 46-51, 2007.

[21] Solaiman , A.R.M., Influence of Rhizobium inoculant, nitrogen and boron on nodulation, dry weight and grain yield of chick pea. Annual Bangladesh Agricultural, 9(1), 75-84, 1999.

[22] Van Hamme, J.D., Singh, A., \& Ward, O.P., Recent advances in petroleum microbiology. Microbiology and Molecular Biology Reviews, 76(4), pp. 503-549, 2003. 